\title{
Design as a Discipline for Postdigital Learning and Teaching: Bricolage and Actor-Network Theory
}

\author{
Adam Matthews ${ }^{1}$ \\ Published online: 8 March 2019 \\ (C) The Author(s) 2019
}

\begin{abstract}
Digital technologies for learning and teaching have promised much in higher education (HE). There has become, however, a dualism between digital and non-digital and a technological determinism which in some cases promotes digital technologies as being innately superior to the non-digital. There is pressure on universities to provide learning and teaching in new ways in the face of regulation, as well as increased numbers and diversity of students. The postdigital perspective allows for the appropriate approaches and tools to be used. Design for learning and teaching in HE has developed interventions which promote use of digital resources, but for some have not yet met the promise of 'enhancing' learning. Moving outside of education, approaches from design as a discipline are sketched out, including design thinking and the epistemology of design. All of these show how designers (in general) go about their work. How designs come about can be analysed by using the framework of people (epistemology), processes (praxeology) and products (phenomenology) in design. Actor-network theory is used as an approach across each stage of this framework, and those designing in HE are encouraged to be bricoleurs, using a variety of tools for the job at hand and to think of the designs as assemblages. The ideas described here are useful for the practices of those involved in the design of learning and teaching.
\end{abstract}

Keywords Postdigital · Design · Design thinking · Learning and teaching $\cdot$ Bricolage · Actor-network theory

\section{Introduction}

Educators frequently use the word design in their practice: designing a module, a curriculum, a lesson, and an online content. Design as a linguistic expression has

Adam Matthews

axm1351@student.bham.ac.uk

1 School of Education, University Of Birmingham, Birmingham, UK 
become so broad that one could argue that it has become too broad to mean anything. Many in education may go about their design work in an explicit, structured manner. Others may have implicit ways of working with tacit knowledge that is 'automatic' and 'second nature'. This paper will begin by looking at the concept of the postdigital and how it may be of use to embed the use of digital technologies into everyday teaching and learning practices, where needed. The paper looks at the current higher education (HE) landscape and some of the approaches being taken. This is followed up by sketching out some of the criticisms of technology for learning in higher education. The article then goes on to examine how the postdigital offers new opportunities to think about the design of learning and teaching activities and resources in a new more considered, non-technologically determined manner, drawing upon academic work in design as an independent discipline. This provides an established framework and analysis of how designers go about their work for consideration in design for learning and teaching. This perspective is of use for those who make design decisions for learning, those involved in the design or carrying out of teaching, those involved in educating teachers, and those who support design for learning. The metaphor of bricolage is put forward as a way of working for educators and design teams to evaluate the tools which they have at hand and to use them in a considered, non-determinist or dualistic manner with a focus on learning. Finally, actor-network theory (ANT) is presented as a valuable theoretical perspective to analyse how designs come about and how they can be created and re-created using bricolage. This is with the aim of providing higher education with new postdigital paradigms of thinking in approaches to design for learning and teaching in practice and for inclusion in education programmes.

\section{The Postdigital}

A meme went viral in 2013 of a man in a park using a typewriter rather than a computer with the words mockingly: 'You're not a real hipster - until you take your typewriter to the park' (Cramer 2015: 12). It turned out to be a writer, running a business providing authentic typewriter-written stories. This encapsulates the postdigital choice: the right tool for the right job and not defaulting to the latest digital device without evaluation. Postdigital is in no way a rejection of the digital but a move towards a mature, evolutionary approach to everyday practices including a rejection of the use of digital in some ways to mean better or improved (Cramer 2015). Fawns describes postdigital education:

All teaching should take account of digital and non-digital, material and social. Ideas like digital education are useful insofar as they encourage people to look closer at what is happening, but become problematic when used to close down ideas or attribute instrumental or essential properties to technology. (Fawns 2018: 11)

While removing the digital and non-digital dualisms may be a way to push forward with how society uses technologies that already exist, Taffel (2016) raises the point that if digital technologies are taken for granted then how can we take a critical view and 
analyse what they are for. Here, by using theory and practice from design and ANT, we can see how digital technologies co-exist in a network with the social, material and natural.

Defining the postdigital is not a straightforward task with many aspects and uses being offered. It is messy and unpredictable, and this in many ways should be embraced as it rejects the binary dualism of the digital and non-digital. The postdigital is a new way of thinking but also a continuation of what has gone before (Jandrić et al. 2018a). Postdigital rejects the idea of old and new media as existing together by blurring of the binary dualistic lines (Jandrić et al. 2018b). Cramer (2015) offers a list of perspectives which is more of a rejection of the digital, citing disenchantment and rejection of the sterility of digital and the universal machine in a corporate implementation of digital. Peters and Besley (2018) also stress that it is not a chronological term which moves us on from one set of technologies to the next but a critical attitude and philosophy which questions and brings to the surface issues and questions which go beyond accepting new technologies as progressive and inevitable. Taffel (2016) describes the variety of fields in which postdigital perspectives are being used, amongst these are architecture, art, film, advertising, photography, e-learning and design. A rejection of the binary for Taffel will enable us to find a discourse in which we can produce designs which are conducive to human and non-human ecologies and their flourishment.

\section{Design for Learning and Teaching in Higher Education}

There is currently a spotlight on teaching and learning in higher education. The current UK higher education sector is under a new regulatory measurement environment which puts a new focus on teaching (and learning). In the UK, the Teaching Excellence Framework (TEF) measures teaching quality, learning environment and student outcomes, and learning gain. The evaluation tool piloted in 2017 is designed to assess quality and to provide market information to students as consumers (Gunn 2018). This approach can also be seen internationally (Gourlay and Stevenson 2017). The manner in which learning and teaching is taking place in the academy is diversifying. As higher education becomes more 'massified', learners are becoming significantly more diverse in a host of characteristics. Demands for more flexible options are needed to meet the diverse needs of students; this includes the internationalisation and transnationalisation of aspects of higher education that are changing learning and teaching.

Many have laid out learning theories which underpin an educator's knowledge and practice. This present work will not take the epistemology of the educationalist in terms of learning theory and practice into consideration but will explore how learning and teaching interventions are designed. One aspect of learning and teaching that is relevant for the following review is that of critical pedagogy. A critical approach to pedagogy is in line with much postdigital thinking which looks to reject technological determinism and to achieve greater agency for learners and those involved in teaching and supporting teaching.

Along with academic teaching staff are a group of professionals working to support learning and teaching, including the use of and promotion of technologies. This group can broadly be described as the academic development community. Sugrue et al. (2017) conducted a systematic review of the literature on academic development. A category 
within this review included the responsibility of implementing technological solutions. The review found that pressure to use technology comes from a range of sources and can often be perceived as being progressive and improving teaching and that one should be using all of the latest technology to be seen as relevant and up to date. Academic developers are described here as key leaders of implementing technology into learning and teaching and providing leadership into the new ways of using such technologies. Many other job roles can also be seen within HE, such as instructional designer, learning designer, e-learning designer, learning technologist and many more. There can often be resistance and tensions across this requirement for multidisciplinary teams, many teachers see themselves as the individual designer and identities of teaching can vary and resist future development (Deaker et al. 2016). There are requirements for diverse backgrounds in this area to collaborate, and those from IT, educational technology and academic practice are being asked to collaborate with each other and with teaching staff. This collaboration is vital to bringing together specialist skillsets to create new learning and teaching environments. Much work from all parties is needed to foster such working relationships and the communication of roles and responsibilities and trusting partnerships is required in this (for many) new way of working (Budge and Clarke 2012; Bayerlein and McGrath 2018). Learning technologists as a sub-group of academic practice are an important group when looking from a postdigital perspective. It is clear that specialists with expertise are required and exist in many organisations, but how these groups work together is still far from clear (Fox and Sumner 2014; Gurbutt and Williams 2018).

\section{Technology for Learning and Teaching}

For many, the promise of technology to 'enhance' learning has not delivered. Kirkwood and Price (2014) conducted a critical literature review of the enhancements of learning technology:

When reviewing the documents identified in the searches, we discovered that many interventions were technology- led (e.g., 'how can we use podcasts/ wikis...?'), rather than being derived from an identified educational need or aspiration. While in some cases this technology-led approach was undoubtedly a response to larger or more diverse classes and encouragement to make greater use of institutional 'learning environments', there seemed to be many cases of deterministic expectations that introducing technology would, by itself, bring about changes in teaching/learning practices. This might contribute to the lack of an explicit educational rationale for many interventions. (Kirkwood and Price 2014: 25)

Henderson et al. (2017) explored the experiences of 1658 students using technology for learning concluding that technologies are being used by students but not transforming or enhancing learning. Technology is being used to be able to access resources, submit work online and communicate with others. The study states that this works well and provides many efficiencies. The issue could here then be the promise of enhancement and disruption of education rather than support and administration. Goodchild and 
Speed (2018) explore the hegemonic discourse of technology enhanced learning stating:

the idea that technology enhances learning is an accepted orthodoxy, a common sense view of teaching and learning, and to resist this view seems to fly in the face of rationality. (Goodchild and Speed 2018: 3)

Goodchild and Speed's discourse analysis confirms that technology in teaching and learning is seen as inevitable and almost separate to learning and teaching. They comment that systems and platforms which provide such technology play a part in a market in which companies are competing for market share which can add to the hegemonic discourse of enhancement through marketing initiatives. This separation of technology from learning characterises the dualism of digital technologies and a determinism which sees technological practices as inherently good and not embedded into the learning experience whole.

Outside of education, Morozov (2013) critiques solutionism which offers technological solutions to many social issues without identifying underlying political and ethical considerations. Much of the critical research on digital learning technologies does not dismiss them as ineffective but asks teachers and implementers to be critical and not become technologically deterministic and part of the hegemonic discourse. Technological determinism and agency are key themes in the postdigital literature. The early utopian idea of the internet being a network of democratic sharing has been subsumed by huge corporations and political interference (Jandrić et al. 2018a). The hegemonic discourse of digital technology having an inherent good has been dismissed as having a lack of criticality, and there are many reminders in a range of discourses that technology and not people achieves and enhances learning (Hayes 2015). A postdigital perspective then looks at the agency of a variety of actors in the face of technological determinism and the dualism of digital and non-digital.

Many institutions have designed workshops and frameworks which look to design 'blended', 'technology-rich', 'technology-enhanced', and 'digital' learning. University College London (UCL) have developed a 90 minute workshop format called ABC to support teachers to storyboard modules. Young and Perović (2016) describe how improving courses by using technology and changing modes of study are supported by the UCL Digital Education team alongside the Centre for Advancing Learning and Teaching. The ABC workshop involves teachers bringing with them their module specification, including learning outcomes, and the aim of the workshop is to create a storyboard of learner activity which then meets the learning outcomes using Laurillard's (2012) Conversational Framework using six learning types. There is a task to differentiate where the 'face to face' and 'online learning' occurs. With a focus on 'future-orientated, digital, student-centered learning' Pathfinder: Carpe Diem (Salmon and Wright 2014) again offers development opportunities for academic teaching staff. Participants are guided through a rapid prototype process to produce online learning, 'they are constantly, but not too overtly, invited to think differently, to incorporate available technology into their learning design'. The 2-day workshop puts educators in touch with educational developers for future developments. Laurillard (2012) sketches out how teaching is and should become a design science-technology is again called upon, in this case, 'the hero of the story' to play a key part in new ways of working. 
Luckin (2010) looks at re-designing learning contexts. Contexts in this case are individual to the learner and their experience of the world. Luckin calls for 'technologyrich learning' to form an ecology of resources. Technology for Luckin plays a vital part in learning experiences and references the work as educational technology. The ecology of resources model then takes into consideration the complexity of each learner's context and asks those who design learning experiences to consider knowledge and skills, tools, people and the environment with the learner at the centre. Technology is treated as a stand-alone independent entity; for example, a learner's ecology of resources includes MAPS (more able partners); these are presented as parent, friend, teacher and technology.

Much of the work reviewed here treats digital and technology as separate entities to be added to non-digital activities as enhancements or improvements. I am not proposing that this work is counter-intuitive to good learning design but it can be questioned as to whether the discourse in such work perpetuates the hegemonic view that technology is inherently good and that designs should aim to include digital over the nondigital regardless of need or separate the two with terms such as 'online learning' and 'face to face learning'. There does also appear to be a lack of analysis of the epistemological aspect of design in many cases. Questions over how designs come about and the strategies used are not overtly explored. I aim to offer some options when looking at the wider field of design below.

Goodyear (2015) looks at teaching as design, drawing upon ideas of design from wider design disciplines. Here, teaching as design is challenging universities to think like designers for economies of scale when time and resources are limited. Design epistemology, design phenomenology and design praxeology-the knowledge of designers of education, what the designers produce and how designers go about this - are used as a conceptual model by Goodyear to think about how those in HE can become more like designers. Goodyear calls for whole institutions to become 'more hospitable environments for design' (Goodyear 2015: 28); this includes faculty structure, programme design, module design, down to individual learning tasks. This is what Goodyear terms 'actionable knowledge for design'. The current design for learning literature sketched here does not appear to have any explicit epistemic approaches. Using the work of design as a discipline, I will offer some possible options for use in design for teaching and learning below. Goodyear's work fits closest with the discipline of design. This present work will now move away from design in the confides of education to look at how thinking from the discipline of design can inform new ways of working as design as a discipline in its own right.

\section{Design as a Discipline}

The ubiquitous and varied use of the word design causes ambiguity when it comes to defining and agreeing what design is. Great buildings and technological innovations are designed, or everyone could be described as a designer:

Designed things are the means by which we achieve desired ends.

(Petroski 2008: 48) 
All men are designers. All that we do, almost all of the time, is design.

(Papanek 1985: 23)

Engineers are not the only professional designers. Everyone designs who devises courses of action aimed at changing existing situations into preferred.

(Simon 1988: 67)

If anyone can design then, how can we come to an agreed definition without attributing design to all of humankind. Parsons (2016) offers a philosophy of design definition: 'Design is the intentional solution of a problem, by the creation of plans for a new sort of thing, where the plans would not be immediately seen, by a reasonable person, as an inadequate solution' (Parsons 2016: 11).

Looking outside of education can give us the opportunity to ask how do educators design and how do they learn how to design? Cross (1982) called for education to rethink the divide of science and humanities and to consider a third aspect of human knlwledge - design and 'designerly ways of knowing'. This includes calling for design to be part of everyone's education and not just professions who design. Cross argued that the sciences and the humanities study what already exists and not what is to be made, in other words designed. Cross (1999) re-iterated that thinking of design as a discipline in its own right can attempt to study people (epistemology), processes (praxeology) and products (phenomenology) in design (a model adopted by Goodyear in education, see above). Cross goes as far as saying that a large area of cognitive development as constructive ways of thinking has been missed by not including design in general education. Here, we can see the beginning of design being thought of as a discipline in its own right, 'design in general' which is not concerned with what is designed but some of the principles, approaches, knowledge and skills which a designer deploys. Dorst (2011) looks at how some of the approaches designers take are different to the traditions of other fields. Dorst states that traditional deduction and induction is not the way that a designer approaches a task. A more productive task to create something new uses an abductive approach where the 'what' and the 'how' are in the hands of the designer to meet a specific outcome. Dorst suggests the ways that designers achieve this is dictated by frames. Frames are the cultural and normative ways of designing in different fields. Breaking out of a particular field's normative practice frame is where innovation can occur according to Dorst. In the first issue of the Design Studies journal, articles were requested that explored design as a discipline in itself, aside from applied practice such as an architect or interaction design (Archer 1979).

The idea of thinking and working like a designer has gained popularity in a wide range of industries. Similar to the ideas that I have explored about design as a discipline, design thinking takes ways that designers go about their work to translate this to almost any situation. These ways of going about solving problems have made their way out of traditional design professions and into designs in business and social policy (amongst others). This can be characterised by the international design agencies such as IDEO who have brought design to the forefront of technology, working with engineers to analyse how users actually go about using products. These design agencies can now be seen to use their approach to design schools, healthcare systems, businesses and social policy (Katz et al. 2015).

Owen (2007) describes the potential of design thinking for those working in social policy. Owen asks how design approaches can be included in the education of non- 
designers, in this case policy makers. The issue to be tackled was how to provide the policy makers with enough skills and knowledge to have conditioned inventiveness, human-centred focus, environment-centred concern, ability to visualise, tempered optimism, bias for adaptivity, predisposition towards multifunctionality, systemic vision, view of the generalist, ability to use language as a tool, affinity for teamwork, facility for avoiding the necessity of choice, self-governing practicality and ability to work systematically with qualitative information (Owen 2007: 25). Kimbell (2011) traces some of the ideas in designing thinking from the 1980 s to the present day. Kimbell categorises design thinking as a cognitive style, a general theory of design which is decoupled from any specific discipline and design thinking as an organisational resource for any organisational innovation, be that in business or public policy. Kimbell (2012) also proposes two alternative ways to look at designdesign as practice and designs in practice. The former observes the activities in which designers undertake to analyse how a designer goes about their work. The latter tracks a product or service beyond the designers' work, beyond engineers and technologists and beyond marketing and how designs are used and re-imagined in practice. This approach gives us the opportunity to see how designs come to be created but also how they are used in real-world practice. The broadening of design thinking beyond traditional design professions then is one that educators could make use of as well considering inclusion in the syllabus of education for those teaching or supporting learning.

\section{The Epistemology of Design}

To ask those in education to then think like designers, we might want to ask what knowledge and approach designers have - the epistemology of design. Simon (1996) called for a science of design which used positivist methods to measure designs quantitatively and use such approaches in the new design of the new artefact. The rigorous science of design approach would collect data to optimise designs. This movement was prevalent in the 1960s but may now be making a return as design thinking is being used in business and management fields. The field of learning analytics in HE represents Simon's work in the quantitative measure of behaviours and computation to look for data which can statistically show patterns of activity for learning (Martin and Sherin 2013).

Rittel and Webber (1973) contrast this view in their highly cited work 'Dilemmas in a general theory of planning'. Here, wicked problems are introduced to describe how issues are tackled in areas such as social policy and wider social sciences. This work says that the natural sciences and positivist approach are 'tame' problems, in contrast to those social issues to be tackled which are 'wicked'. Tame problems are measurable with clear outcomes; wicked problems have many consequences and can often be termed good or bad, rather than true or false. Moreover, wicked problems can be designed to be resolved but the complexity of the social issue may have unforeseen effects on another area which has not or could not possibly considered. A tame problem can be studied in a controlled environment, but a wicked problem is in the real, messy unstructured environment of the 'real' world. Schön (1983) looks at design professionals in practice and how they go about their work. In contrast to the technocratic, 
objective and positivist approached described previously, Schön was interested in the implicit knowledge of practitioners who used their experience and know how to solve problems in a much more idiosyncratic, interpretivist and constructive manner.

Krippendorff (2006) boldly claimed that 'Design is making sense of things' and that design has to undergo a 'semantic turn'. This turn, Krippendorff stated, should not merely be interested in how mechanical products look and to turn away from a technology-centred approach to a human-centred design. Here, meaning is giving significant importance to whatever is being designed and that meaning matters more than function. A designer's role according to Krippendorf is to take on second-order understanding to interpret and design for technological, social and cultural consequences for stakeholders. Stakeholders here are anyone involved in the designed artefacts and the ecology of artefacts. The three cornerstone pieces of work from Simon, Schön and Krippendorf have their similarities and obvious differences: Simon's positivist, computational approach; Schön's human interpretivist element and Krippendorff's ecology of designed artefacts and stakeholders (Galle 2011).

\section{Bricolage and Actor-Network Theory for Postdigital Design for Learning}

Postdigital design for learning needs a set of new ways of going about design that do not draw upon the divide between digital and non-digital and that does not slip into previous frames of thinking, dualisms or technological determinism. Here, I would like to introduce the ideas of bricolage and actor-network theory (ANT). Claude LeviStrauss used the idea of bricolage in the The Savage Mind to describe untamed human thought. There is no direct translation to English (from French) of bricolage/bricoleur (the closest being a higher status 'odd-job man'), but a bricoleur is someone that comes up with solutions using what is at hand and to pull these things together to make something new (Lévi-Strauss 2000). Levi-Strauss compares the engineer with the bricoleur. The engineer asks scientific questions and creates optimal solutions. The bricoleur in contrast pulls together what is at hand, ready or half made to make something new, regardless of what it is.

Such elements are specialized up to a point, sufficiently for the 'bricoleur' not to need the equipment and knowledge of all trades and professions, but not enough for each of them to have only one definite and determinate use. They each represent a set of actual and possible relations; they are 'operators' but they can be used for any operations of the same type. (Lévi-Strauss 2000: 11)

This quote shows how those involved in design for learning do not need to be specialists in all fields but to have an appreciation and ability to evaluate if it is the right tool for the job in line with the context of postdigital design for learning. Bricolage is used as a metaphor for the design process which aims to give structure to events (Louridas 1999).

ANT moves away from traditional epistemological and ontological boundaries. Founded in the discipline of science and technology studies, ANT removes barriers by talking about human and non-human entities as equals acting upon each other in a 
constructing and deconstructing manner, these can be humans, objects, ideas, social norms, nature, cultural histories, symbolic values and many more, all in a relativist manner to trace connections. All of these entities form nodes in a network and negotiate with one another to create actions; this is in contrast to qualitative approaches which may ask what they mean (Fenwick and Edwards 2010). Actions are produced when a variety of entities (human and non-human) come together, and this may be coincidentally or in a designed manner; ANT refers to this collection of things as assemblages (Müller and Schurr 2016). Agency of these actors then is not something which comes under full consciousness but a coming together of each of the nodes in the network. ANT is a tool which enables one to untangle these knots and nodes in the network to analyse the action of entities (Latour 2007). Neyland (2006) characterises ANT as getting to grips with the mundane, assemblages, materiality, heterogeneity and flows/fluidity. This summary shows how ANT looks at the everyday actions which are brought about by the assembly of things which shows how they come together in a diverse fashion in a non-stable manner, they are constantly made, become stable but often remade.

Latour (2007) describes what makes up ANT analysis through five uncertainties. Groups do not just exist, they are formed, and this is how we can best analyse them through their formations. Action is important and how actors act based on other actors form part of the ANT analysis and these are constantly debated. Objects have agency and can be seen as determining action or simply used for a social action; Latour says that objects can permit, suggest, influence, block etc. ANT's epistemology is constructed much like a building in that different elements are brought together in the network and the associations with nodes in the network. This is problematic for Latour as other social sciences use his selected term 'social constructivism' in very different ways, often ways which dismiss scientific objectivity. Social constructivism within ANT looks at knowledge as bringing together both the social, natural and technical. ANT is reported simply as 'an account which traces a network' (Latour 2007). This looks at the network which actions of actors make other actors do unexpected things. A challenge for those using ANT is how far the network should spread and when to stop analysing connections. All of this makes up a sociology of associations.

Two examples are provided by Latour. The size of a hotel room key influences and changes the actions of the hotel guest. A small key fob which fits into the pocket of the guest encourages their action to place the key in the pocket and not hand it in to reception. A larger key which cannot be placed easily in a pocket influences the guest to act and hand the key in at reception and potentially mitigates the risk of losing the key (Latour 2007). Tracing associations and actions is also termed as the black box. This is where an entity is taken for granted, in this particular example, a camera. There are many parts that go into making a camera and many design decisions. What is included and excluded and who makes those decisions are all actors in ANT. The camera is taken for granted, but when opening up the black box, ANT allows one to explore how it is come to be and how it becomes stable and taken for granted (Latour 2003).

Latour (1996) points out two common misunderstandings: (1) The word network can be misleading and make people think of technical similarities to physical networks which are stable and fixed. (2) A researcher may look just at the social and ignores artefacts, ideas and technologies. To use ANT effectively, all should be given equal standing and have an influence on each other. 
Taking Latour's metaphor of construction, of elements being brought together - the social, natural and technical in a sociology of associations, we can look towards a hypothetical example in HE. Consider an undergraduate module which makes up a degree programme. A designer (whoever that may be) has the task of bringing together an assemblage of resources. The assemblage could include weekly lectures, followed up by small seminar group teaching; the lectures may be recorded; online activities or content may be shared with students and activities may be set for before or after the lecture or seminar online. There may be an element of open networked learning (Hodgson and McConnell 2019) and open resources such as blogs, news articles and YouTube videos used by students independently or provided for them. These elements described all have influence upon each other. Each interaction with an element of the assemblage will change and reshape the other. Each student and teacher will bring their own past experiences and knowledge to bear on the network. The institutional norms and technical systems will play a part in what can be done and how it is done. This signifies the messy real world which Latour embraces and says cannot be avoided. Where should the sociology of associations begin and end and which black boxes should be opened and which left unopened? This is a decision for designers, researchers and stakeholders and will always be a pragmatic one. Pragmatism can be offered by the bricoleur who has to use the tools at hand; what is available, who is available to help and what works are the pragmatic questions of our bricoleur in the design of learning and teaching. This signifies the postdigital in that we cannot and are making a mistake to differentiate and separate the digital from the non-digital. As Cramer (2015) points out, the postdigital is DIY in contrast to a corporatized approach. The postdigital drags the smooth standardised digital down into the mud (Jandric et al. 2018b) to work with all actors in the assemblages.

\section{Towards a Postigital Actor-Network Theory Bricolage of Design for Learning}

We have seen in HE learning and teaching, in some cases, somewhat of a dualism between the digital and non-digital and in some cases a technological determinism. This paper has illuminated some of the thinking in the field of design that may enable postdigital practices to be adopted in HE and for those designers to join the wider design as a discipline community. I have attempted to do this to look at the field of design and what it means to be a designer and the epistemological variances within the field. The popular use of design thinking has permeated into different and diverse fields including public policy and business management. In a time when higher education is facing an increased focus on learning and teaching and the massification of the HE sector, the use of design methods and identifying roles in the design process can be of use to design new approaches which are needed in these new contexts.

Using the framework of people (epistemology), processes (praxeology) and products (phenomenology) (Cross 1999; Goodyear 2015), we can study the knowledge used by those involved in the design process or the knowledge required, the processes by which they work and the products which they provide for learning and teaching. By sketching ideas from design within $\mathrm{HE}$ and as design as a discipline in itself, this paper offers starting points for decisions and discussions in who is involved in design and what 
skills and knowledge they bring. How these individuals and teams go about design must also be of study and practical application in what goes into the design process (praxeology). Finally, the end product and how it is used by learners and educators (phenomenology) must be researched for effectiveness. Here, I propose a framework for analysing how designs come to be as well as enabling designs.

To achieve this in the postdigital epoch, ANT can play a part across all three aspects of the design framework. ANT, with no bias between the human and non-human, traces the sociology of associations in designs in practice. The designer then, whether looking to design anew or reconfigure an existing design can be seen as the bricoleur, always on the lookout for what is at hand, to use in a suitable way, in a critical, postdigital way for learning and teaching which can be re-used and re-assembled to meet the need of the situation at hand regardless of the digital/non-digital, aware of critical pedagogy, not to be seduced by the technological determinist discourse and to increase agency for all involved. This can then be described as a design for postdigital learning and teaching where the appropriate design assemblage is used for the appropriate situation.

\section{Compliance with Ethical Standards}

Conflict of Interest The authors declare that they have no conflict of interest.

Open Access This article is distributed under the terms of the Creative Commons Attribution 4.0 International License (http://creativecommons.org/licenses/by/4.0/), which permits unrestricted use, distribution, and reproduction in any medium, provided you give appropriate credit to the original author(s) and the source, provide a link to the Creative Commons license, and indicate if changes were made.

\section{References}

Archer, B. (1979). The three Rs. Design Studies, 1(1), 18-20.

Bayerlein, L., \& McGrath, N. (2018). Collaborating for success: an analysis of the working relationship between academics and educational development professionals. Studies in Higher Education, 43, 10891106. https://doi.org/10.1080/03075079.2016.1215417.

Budge, K., \& Clarke, A. (2012). Academic development is a creative act. International Journal for Academic Development, 17, 59-70. https://doi.org/10.1080/1360144X.2011.587192.

Cramer, F. (2015). What is "post-digital"? In D. M. Berry \& M. Dieter (Eds.), Postdigital aesthetics (pp. 1226). London: Palgrave Macmillan UK.

Cross, N. (1982). Designerly ways of knowing. Design Studies, 3, 221-227. https://doi.org/10.1016/0142-694 $\mathrm{X}(82) 90040-0$.

Cross, N. (1999). Design research: a disciplined conversation. Design Issues, 15, 5. https://doi.org/10.2307 $/ 1511837$.

Deaker, L., Stein, S. J., \& Spiller, D. (2016). You can’t teach me: exploring academic resistance to teaching development. International Journal for Academic Development, 21, 299-311. https://doi.org/10.1080 /1360144X.2015.1129967.

Dorst, K. (2011). The core of “design thinking” and its application. Design Studies, 32, 521-532. https://oi. org/10.1016/j.destud.2011.07.006.

Fawns, T. (2018). Postdigital education in design and practice. Postdigital Science and Education. https://doi. org/10.1007/s42438-018-0021-8 .

Fenwick, T. J., \& Edwards, R. (2010). Actor-network theory in education. New York: Routledge.

Fox, O., \& Sumner, N. (2014). Analyzing the roles, activities, and skills of learning technologists: a case study from City University London. American Journal of Distance Education, 28, 92-102. https://oi. org/10.1080/08923647.2014.897465. 
Galle, P. (2011). Foundational and instrumental design theory. Design Issues, 27(4), 81-94.

Goodchild, T., \& Speed, E. (2018). Technology enhanced learning as transformative innovation: a note on the enduring myth of TEL. Teaching in Higher Education, 1-16. https://doi.org/10.1080 /13562517.2018.1518900.

Goodyear, P. (2015). Teaching as design. HERDSA Review of Higher Education, 2, 27-50.

Gourlay, L., \& Stevenson, J. (2017). Teaching excellence in higher education: critical perspectives. Teaching in Higher Education, 22, 391-395. https://doi.org/10.1080/13562517.2017.1304632.

Gunn, A. (2018). Metrics and methodologies for measuring teaching quality in higher education: developing the Teaching Excellence Framework (TEF). Education Review, 70, 129-148. https://doi.org/10.1080 /00131911.2017.1410106.

Gurbutt, D. \& Williams, K. (2018) Performing good teaching: the frontstage and backstage work of Interdisciplinary Working, 12th International Technology, Education and Development Conference. https://doi.org/10.21125/inted.2018.0274.

Hayes, S. (2015). Counting on the use of technology to enhance learning. In P. Jandrić \& D. Boras (Eds.), Critical learning in digital networks (pp. 15-36). New York: Springer.

Henderson, M., Selwyn, N., \& Aston, R. (2017). What works and why? Student perceptions of "useful" digital technology in university teaching and learning. Studies in Higher Education, 42, 1567-1579. https://doi.org/10.1080/03075079.2015.1007946.

Hodgson, V., \& McConnell, D. (2019). Networked learning and postdigital education. Postdigital Science and Education. https://doi.org/10.1007/s42438-018-0029-0 .

Jandrić, P., Knox, J., Besley, T., Ryberg, T., Suoranta, J., \& Hayes, S. (2018a). Postdigital science and education. Educational Philosophy and Theory, 50, 893-899. https://doi.org/10.1080 /00131857.2018.1454000.

Jandrić, P., Ryberg, T., Knox, J., Lacković, N., Hayes, S., Suoranta, J., Smith, M., Steketee, A., Peters, M., McLaren, P., Ford, D. R., Asher, G., McGregor, C., Stewart, G., Williamson, B., \& Gibbons, A. (2018b). Postdigital dialogue. Postdigital Science and Education. https://doi.org/10.1007/s42438-018-0011-x .

Katz, B. M., Maeda, J., \& Antonelli, J. (2015). Make it new: the history of Silicon Valley design. Cambridge: MIT Press.

Kimbell, L. (2011). Rethinking design thinking: part I. Design and Culture, 3, 285-306. https://doi. org/10.2752/175470811X13071166525216.

Kimbell, L. (2012). Rethinking design thinking: part II. Design and Culture, 4, 129-148. https://doi. org/10.2752/175470812X13281948975413.

Kirkwood, A., \& Price, L. (2014). Technology-enhanced learning and teaching in higher education: what is "enhanced" and how do we know? A critical literature review. Learning, Media and Technology, 39, 636. https://doi.org/10.1080/17439884.2013.770404.

Krippendorff, K. (2006). The semantic turn. Boca Raton: CRC.

Latour, B. (1996). On actor-network theory: a few clarifications. Soziale Welt, 47(4), 369-381.

Latour, B. (2003). Science in action: how to follow scientists and engineers through society. Cambridge: Harvard Univ. Press.

Latour, B. (2007). Reassembling the social: an introduction to actor-network-theory. Oxford: Oxford Univ. Press.

Laurillard, D. (2012). Teaching as a design science. New York: Routledge.

Lévi-Strauss, C. (2000). The savage mind. Chicago: Univ. of Chicago Press.

Louridas, P. (1999). Design as bricolage: anthropology meets design thinking. Design Studies, 20, 517-535. https://doi.org/10.1016/S0142-694X(98)00044-1.

Luckin, R. (2010). Re-designing learning contexts: technology-rich, learner-centred ecologies. New York: Routledge.

Martin, T., \& Sherin, B. (2013). Learning analytics and computational techniques for detecting and evaluating patterns in learning: an introduction to the special issue. The Journal of the Learning Sciences, 22, 511520. https://doi.org/10.1080/10508406.2013.840466.

Morozov, E. (2013). To save everything, click here: the folly of technological solutionism. New York: PublicAffairs.

Müller, M., \& Schurr, C. (2016). Assemblage thinking and actor-network theory: conjunctions, disjunctions, cross-fertilisations. Transactions of the Institute of British Geographers, 41, 217-229. https://doi. org/10.1111/tran.12117.

Neyland, D. (2006). Dismissed content and discontent: an analysis of the strategic aspects of actor-network theory. Science, Technology \& Human Values, 31, 29-51. https://doi.org/10.1177/0162243905280022.

Owen, C. (2007). Design thinking: notes on its nature and use. Design Research Quarterly, 2(1), 16-27. 
Papanek, V. (1985). Design for the real world: human ecology and social change. London: Thames \& Hudson.

Parsons, G. (2016). The philosophy of design. Cambridge, UK: Polity Press.

Peters, M. A., \& Besley, T. (2018). Critical philosophy of the postdigital. Postdigital Science and Education. https://doi.org/10.1007/s42438-018-0004-9 .

Petroski, H. (2008). Success through failure: the paradox of design. Princeton, NJ: Princeton University Press.

Rittel, H., \& Webber, M. (1973). Dilemmas in a general theory of planning. Policy Sciences, 4, 155-169.

Salmon, G., \& Wright, P. (2014). Transforming future teaching through "Carpe Diem” learning design. Education Sciences, 4, 52-63. https://doi.org/10.3390/educsci4010052.

Schön, D. A. (1983). The reflective practitioner: how professionals think in action. New York: Basic Books.

Simon, H. A. (1988). The science of design: creating the artificial. Design Issues, 4, 67. https://doi.org/10.2307 /1511391.

Simon, H. A. (1996). The sciences of the artificial. Cambridge: MIT Press.

Sugrue, C., Englund, T., Solbrekke, T. D., \& Fossland, T. (2017). Trends in the practices of academic developers: trajectories of higher education? Studies in higher education, 43, 2336-2353. https://doi. org/10.1080/03075079.2017.1326026.

Taffel, S. (2016). Perspectives on the postdigital: beyond rhetorics of progress and novelty. Convergence: The International Journal of Research into New Media Technologies. https://doi.org/10.1080 /03075079.2017.132602610.1177/1354856514567827.

Young, C., \& Perović, N. (2016). Rapid and creative course design: as easy as ABC? Procedia - Social and Behavioral Sciences, 228, 390-395. https://doi.org/10.1016/j.sbspro.2016.07.058. 